\title{
Research, development, and application of amorphous nickel alloy catalysts prepared by melt-quenching
}

\author{
ZONG Baoning a,*, MU Xuhong a , ZHANG Xiaoxin a, MENG Xiangkun a, QIAO Minghua ${ }^{b}$ \\ a State key Laboratory of Catalytic Materials and Reaction Engineering, Research Institute of Petroleum Processing, Sinopec, Beijing 100083, China \\ b Department of Chemistry and Shanghai Key Laboratory of Molecular Catalysis and Innovative Materials, Fudan University, Shanghai 200433, China
}

\section{A R T I C L E I N F O}

\section{Article history:}

Received 20 December 2012

Accepted 19 January 2013

Published 20 May 2013

\section{Keywords:}

Amorphous alloy

Skeletal nickel

Hydrogenation

Desulfurization

Industrialization

\begin{abstract}
A B S T R A C T
Raney Ni is one of the most widely used catalysts in the petrochemical industry. This material's intrinsic catalytic activity for hydrogenation may be enhanced by transforming the crystalline Ni-based alloy into an amorphous structure via melt-quenching. The meta-stability and low specific surface area of such amorphous alloys, however, can severely restrict their catalytic applications. Our work has demonstrated that the incorporation of rare earth (RE) elements increases the crystallization temperature of an amorphous Ni catalyst by $200 \mathrm{~K}$. Related experimentation has determined that the specific surface area of such catalysts is dramatically increased by two orders of magnitude following alloying with $\mathrm{Al}$ and subsequent caustic leaching. In addition, by introducing a third metal as a promoter, the hydrogenation selectivity, corrosion resistance and magnetism of these materials may be precisely adjusted, giving rise to a family of skeletal amorphous $\mathrm{Ni}$ alloy catalysts, to which we apply the trade name SRNA. Among these catalysts, the SRNA- 1 catalyst is used for the hydrogenation of pharmaceutical intermediates, SRNA-2 is employed for the hydrogenation of glucose into sorbitol, SRNA-3 is effective in the adsorptive desulfurization of gasoline and diesel and SRNA-4 is used for the purification of caprolactam. In addition, the SRNA- 5 catalyst is useful in the hydrogenation of benzoic acid as a partial substitute for the costly Pd/C catalyst, reducing consumption of the latter during the hydrogenation process by almost $50 \%$.
\end{abstract}

(C) 2013, Dalian Institute of Chemical Physics, Chinese Academy of Sciences. Published by Elsevier BV. All rights reserved.
The Raney Ni catalyst, developed by Murray Raney in 1925, is currently very commonly employed as a hydrogenation catalyst in the pharmaceutical, agrochemical, and petrochemical industries and has reached a level of significant technical maturity [1]. Thus, to achieve further significant improvements in the area of catalytic materials, great strides in catalytic performance are required, along with the development of associated advanced reaction engineering techniques suitable for use with new catalytic materials.

Amorphous metal alloys are a relatively new catalytic material which have structures with short-range order but long-range disorder and which exhibit useful catalytic proper- ties. Since the pioneering paper on the catalytic performance of amorphous metal alloys appeared in 1981 [2], these materials have remained some of the most heavily researched catalysts. Although the intrinsic catalytic activity of amorphous metal alloys is usually higher than that of the corresponding crystalline metals, their meta-stability and low specific surface area have severely restricted their practical applications. To date, except that our research group has been successful in demonstrating the manufacture and application of various amorphous metal alloy catalysts on an industrial scale, most studies concerning these materials have been restricted to the laboratory or pilot-plant scale.

\footnotetext{
* Corresponding author. Tel/Fax: +86-10-82368011; E-mail: zongbn.ripp@sinopec.com This work was supported by the National Basic Research Program of China (973 Program, 2012CB224806). DOI: 10.1016/S1872-2067(11)60486-5 | http://www.sciencedirect.com/science/journal/18722067 | Chin. J. Catal., Vol. 34, No. 5, May 2013
} 


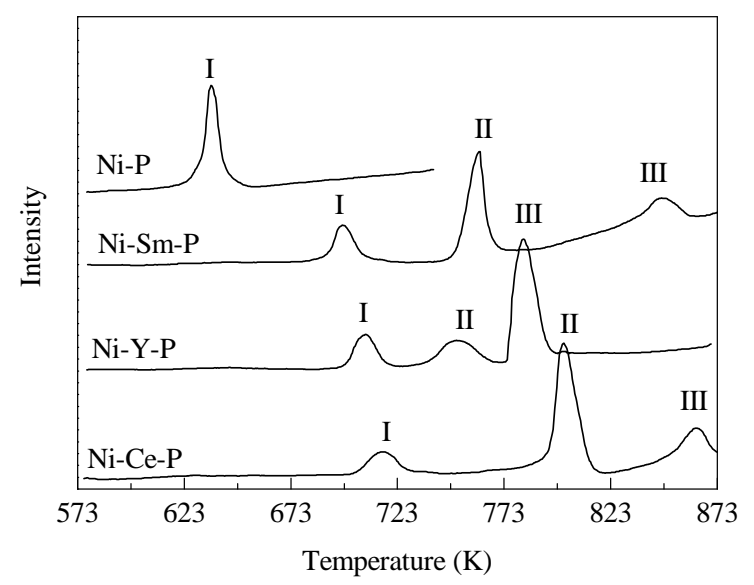

Fig. 1. DSC traces for amorphous Ni-P and Ni-RE-P alloy catalysts. Cited from Ref. [3].

\section{Improvement of thermal stability of amorphous $\mathrm{Ni}-\mathrm{P}$ alloys [3]}

\subsection{Thermal stability of amorphous Ni-P and Ni-RE-P alloys}

One shortcoming of amorphous alloys which limits their practical applications in catalysis is their meta-stability. However, if an alloy's crystallization temperature is sufficiently greater than the temperature of the reaction to which it is applied, it is possible for the amorphous alloy to maintain its high catalytic activity over a suitably long lifetime, without loss of the alloy's amorphous structure. In the case of the amorphous $\mathrm{Ni}-\mathrm{P}$ alloy, its crystallization temperature is $629 \mathrm{~K}$. One goal of our work was to further improve the thermal stability of this material by incorporating the rare earth (RE) elements Ce, Y or Sm into the alloy. This approach was adopted because it is known that the presence of RE atoms with large radii can retard the diffusion of $\mathrm{Ni}$ atoms, which is a prerequisite for the crystallization of the amorphous Ni-P alloy [4].

Amorphous Ni-P and Ni-RE-P (RE = Ce, Y, and Sm) alloys were prepared via a melt-quenching technique, by which amorphous alloy ribbons $2 \mathrm{~mm}$ wide and $20 \mu \mathrm{m}$ thick were obtained. Chemical analysis of the resulting alloys found atomic ratios of $\mathrm{Ni}_{82.0} \mathrm{P}_{18.0}, \quad \mathrm{Ni}_{82.0} \mathrm{Ce}_{0.31} \mathrm{P}_{17.7}, \quad \mathrm{Ni}_{82.0} \mathrm{Y}_{0.25} \mathrm{P}_{17.7}$ and $\mathrm{Ni}_{82.0} \mathrm{Sm}_{0.15} \mathrm{P}_{17.8}$. Figure 1 shows the differential scanning calorimetry (DSC) traces obtained for the Ni-P and Ni-RE-P alloys and the data derived from the figure are summarized in Table 1. It can be seen that there was only one exothermic peak for the Ni-P alloy but three peaks for the RE-modified alloys, and that the initial crystallization temperature of the amorphous $\mathrm{Ni}-\mathrm{P}$ alloy was $629 \mathrm{~K}$, while those of the Ni-Ce-P, Ni-Y-P, and

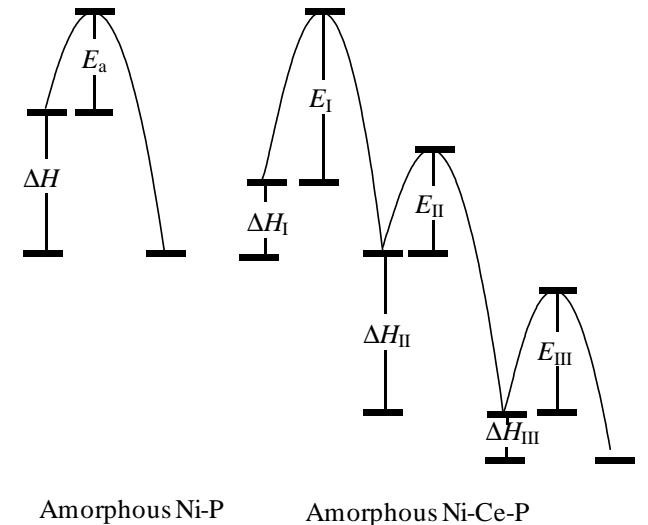

Fig. 2. Schematic illustration of potential energy barriers during the crystallization of amorphous Ni-P and Ni-Ce-P alloys. Cited from Ref. [3].

Ni-Sm-P alloys were 88, 82, and $71 \mathrm{~K}$ higher, respectively. Furthermore, the peak maxima for the main exothermic peaks of the Ni-Ce-P, Ni-Y-P, and Ni-Sm-P alloys were 795, 787, and 742 $\mathrm{K}$, respectively, and the corresponding enthalpy changes of crystallization $(\Delta H)$ were $2.10,2.33$, and $1.71 \mathrm{~kJ} / \mathrm{mol}$. These results unambiguously demonstrate that the addition of only a small amount of a RE element can lead to a remarkable increase in the crystallization temperature of the Ni-P alloy. This technique thus provides a simple and practical means of improving the thermal stability of the amorphous alloy, so as to avoid catalyst deactivation due to collapse of the amorphous structure.

\subsection{The crystallization kinetics of amorphous Ni-P and Ni-RE-P alloys}

To gain a better understanding of the beneficial effects of RE elements on the thermal stability of the Ni-P alloy, the activation energy of crystallization $\left(E_{\mathrm{a}}\right)$ was measured for different alloys, as a means to account for their differing thermal behaviors. To obtain these $E_{\text {a }}$ values, a numbers of DSC curves were generated at different heating rates $(\beta)$ and crystallization temperatures were recorded at the time at which the first formation of microcrystallites was observed through X-ray diffraction (XRD). Based on a sample's crystallization temperature $\left(T_{p}\right)$ and $\beta, E_{\text {a }}$ was calculated according to the Kissinger equation, as follows:

$$
\mathrm{d}\left(\ln T_{p}^{2} / \beta\right) / \mathrm{d}\left(1 / T_{p}\right)=E_{\mathrm{a}} / \mathrm{R}
$$

Here, $E_{\mathrm{a}}$ represents the potential energy barrier between two different phases. The larger the value of $E_{\mathrm{a}}$ is, the more difficult is the transformation between the two phases. As shown in

Table 1

Summary of DSC results for amorphous Ni-P and Ni-RE-P alloy catalysts. Cited from Ref. [3].

\begin{tabular}{|c|c|c|c|c|c|c|c|c|c|}
\hline \multirow[b]{2}{*}{ Catalyst } & \multicolumn{3}{|c|}{ Peak I } & \multicolumn{3}{|c|}{ Peak II } & \multicolumn{3}{|c|}{ Peak III } \\
\hline & $\begin{array}{c}T_{\mathrm{p}} \\
(\mathrm{K}) \\
\end{array}$ & $\begin{array}{c}\Delta H \\
(\mathrm{~kJ} / \mathrm{mol})\end{array}$ & $\begin{array}{c}E_{\mathrm{a}} \\
(\mathrm{kJ} / \mathrm{mol})\end{array}$ & $\begin{array}{c}T_{\mathrm{p}} \\
(\mathrm{K}) \\
\end{array}$ & $\begin{array}{c}\Delta H \\
(\mathrm{~kJ} / \mathrm{mol})\end{array}$ & $\begin{array}{c}E_{\mathrm{a}} \\
(\mathrm{kJ} / \mathrm{mol})\end{array}$ & $\begin{array}{c}T_{\mathrm{p}} \\
(\mathrm{K}) \\
\end{array}$ & $\begin{array}{c}\Delta H \\
(\mathrm{~kJ} / \mathrm{mol})\end{array}$ & $\begin{array}{c}E_{\mathrm{a}} \\
(\mathrm{kJ} / \mathrm{mol})\end{array}$ \\
\hline Ni-P & 629 & 1.83 & 225.7 & - & - & - & - & - & - \\
\hline $\mathrm{Ni}-\mathrm{Ce}-\mathrm{P}$ & 717 & 0.60 & 415.2 & 795 & 2.10 & 326.4 & 860 & 0.19 & 345.6 \\
\hline Ni-Y-P & 711 & 0.39 & 538.3 & 752 & 0.14 & 464.6 & 784 & 2.33 & 501.7 \\
\hline Ni-Sm-P & 700 & 0.52 & 545.3 & 742 & 1.71 & 397.8 & 846 & 0.15 & 618.6 \\
\hline
\end{tabular}


Table 1, $E_{\mathrm{a}}$ for the Ni-P alloy was $225.7 \mathrm{~kJ} / \mathrm{mol}$, while values for the Ni-Ce-P, Ni-Y-P, and Ni-Sm-P alloys were all greater, at $415.2,538.3$, and $545.3 \mathrm{~kJ} / \mathrm{mol}$, respectively. It is evident that, following the incorporation of RE elements, the $E_{\text {a }}$ associated with the transformation between the amorphous phase and the crystalline phase was increased considerably, leading to improved thermal stability of the RE-modified alloys. Based on the data in Table 1, Figure 2 presents a schematic illustration of the potential energy barriers during crystallization of the Ni-P and Ni-Ce-P alloys (presented as a representative of the RE-modified alloys).

It has been noted that $E_{\text {a }}$ correlates well with the apparent activation enthalpy for viscous flow, suggesting that viscosity is the rate-determining factor during crystallization [5]. When incorporating $\mathrm{Ce}, \mathrm{Y}$ or $\mathrm{Sm}$ into the Ni-P alloy, it is reasonable to anticipate that these large RE atoms will effectively slow the diffusion of $\mathrm{Ni}$ and $\mathrm{P}$ atoms during thermal treatment, thus improving the thermal stability of the alloy.

\section{Preparation of a high surface-area skeletal amorphous Ni-P alloy catalyst $[3,6]$}

\subsection{Physicochemical properties of skeletal amorphous Ni-P alloy catalyst}

Because of the extremely low specific surface area of as-quenched amorphous Ni-P alloys $\left(\sim 0.1 \mathrm{~m}^{2} / \mathrm{g}\right)$, these alloys are usually treated with subsequent pulverization, oxidation or reduction to increase their specific surface area and thus improve their catalytic activity. Such treated alloys, however, still exhibit a relatively low specific surface area of $2 \mathrm{~m}^{2} / \mathrm{g}$, which is much smaller than that of either the Raney Ni catalyst or the supported Ni catalysts. As a result, the prospects for industrial application of amorphous Ni-P alloy catalysts are currently limited and it would be highly beneficial to develop a simple, efficient method to increase the specific surface area of these alloys.

Based on existing methods for the preparation of Raney Ni catalysts with a sponge-like structure, we incorporated $\mathrm{Al}$ into the amorphous Ni-P alloy during the initial melt-quenching process. The $\mathrm{Al}$ in the resulting ternary alloy was then leached out with an alkaline solution to generate a porous structure. The amorphous structures of the ternary Ni-Al-P alloy and the resulting skeletal Ni-P alloy catalyst were confirmed by XRD. The results in Table 2 show that the specific surface area of the skeletal Ni-P alloy prepared in this manner increased dramatically to $106 \mathrm{~m}^{2} / \mathrm{g}$ (comparable with that of the Raney Ni catalyst), verifying the utility of our preparation method. The active surface area as determined by $\mathrm{H}_{2}$ adsorption was $48.5 \mathrm{~m}^{2} / \mathrm{g}$, which is slightly higher than that of the Raney Ni catalyst, infer-

\section{Table 2}

Physicochemical properties of the skeletal amorphous Ni-P alloy catalyst. Cited from Ref. [3].

\begin{tabular}{lcccc}
\hline Catalyst & $\begin{array}{c}\text { Bulk composition } \\
\text { (atomic ratio) }\end{array}$ & $\begin{array}{c}A_{\text {BET }} \\
\left(\mathrm{m}^{2} / \mathrm{g}\right)\end{array}$ & $\begin{array}{c}V_{\text {pore }} \\
\left(\mathrm{cm}^{3} / \mathrm{g}\right)\end{array}$ & $\begin{array}{c}A_{\text {act }} \\
\left(\mathrm{m}^{2} / \mathrm{g}\right)\end{array}$ \\
\hline Skeletal Ni-P & $\mathrm{Ni}_{68} \mathrm{Al}_{25} \mathrm{P}_{7}$ & 106 & 0.10 & 48.5 \\
Raney Ni & $\mathrm{Ni}_{68} \mathrm{Al}_{32}$ & 94 & 0.06 & 45.0 \\
\hline
\end{tabular}

Table 3

Activities of catalysts for the liquid-phase hydrogenation of styrene to ethyl benzene. Cited from Ref. [3].

\begin{tabular}{lcccc}
\hline \multirow{2}{*}{ Catalyst } & \multicolumn{4}{c}{ Specific activity (g/g) } \\
\cline { 2 - 5 } & $353 \mathrm{~K}$ & $363 \mathrm{~K}$ & $373 \mathrm{~K}$ & $383 \mathrm{~K}$ \\
\hline Skeletal Ni-P & 15.3 & 18.5 & 23.6 & $27.3^{\mathrm{b}}$ \\
Ni-Sm-P & 0.0 & 0.0 & 0.2 & - \\
Raney Ni & 15.9 & 18.7 & 21.2 & 26.5 \\
\hline
\end{tabular}

Reaction conditions: 2.5 g catalyst, $50 \mathrm{ml} 30$ vol\% styrene in cyclohexane, $\mathrm{H}_{2}$ pressure $4 \mathrm{MPa}$, stirring at $29 \mathrm{r} / \mathrm{min}$, reaction time $1 \mathrm{~h}$.

bUnder these conditions, styrene was completely hydrogenated in $1 \mathrm{~h}$ and $1.1 \%$ of the ethyl benzene product was further hydrogenated to ethyl cyclohexane.

ring that the catalytic activity of the skeletal $\mathrm{Ni}-\mathrm{P}$ catalyst is potentially greater than that of the conventional Raney Ni catalyst.

\subsection{The hydrogenation activity of the skeletal amorphous Ni-P alloy catalyst}

Table 3 compares the catalytic activities for the liquid-phase hydrogenation of styrene between the skeletal Ni-P catalyst, the amorphous NiSmP catalyst treated under optimized oxidation-reduction conditions (which exhibited the greatest activity among the Ce, Y, and Sm-modified alloys) and the Raney $\mathrm{Ni}$ catalyst. The reaction conditions under which catalysis was measured are also given in this table. The specific catalytic activity for each material is expressed as the ratio of the mass of styrene converted to ethyl benzene per hour to the mass of catalyst employed. It is evident that the weight-normalized specific activity of the activated amorphous Ni-Sm-P catalyst is much lower than that of the Raney Ni catalyst, which we attribute to the amorphous catalyst's significantly lower specific surface area. The specific activity of the skeletal Ni-P alloy is similar to that of the Raney Ni catalyst at 353 and $363 \mathrm{~K}$. At higher reaction temperatures, however, the skeletal Ni-P alloy is more active than the Raney Ni catalyst. Using the skeletal Ni-P at 383 $\mathrm{K}$, all available styrene was converted to ethyl benzene and, in addition, $1.1 \%$ of the ethyl benzene was further hydrogenated to ethyl cyclohexane. Using the Raney Ni catalyst under the same conditions, unreacted styrene remained.

Because the hydrogenation of styrene to ethyl benzene proceeded readily over both catalysts, the liquid-phase hydrogenation of toluene to methyl cyclohexane was examined to further differentiate their catalytic activities. The reaction conditions for these tests are given in Table 4. It was determined that, under these conditions, the catalytic activity of the skeletal

\section{Table 4}

Activities of catalysts for the gas-phase hydrogenation of toluene to methyl cyclohexane. Cited from Ref. [3].

\begin{tabular}{lcccc}
\hline \multirow{2}{*}{ Catalyst } & \multicolumn{4}{c}{ Specific activity (g/g) } \\
\cline { 2 - 5 } & $373 \mathrm{~K}$ & $393 \mathrm{~K}$ & $413 \mathrm{~K}$ & $433 \mathrm{~K}$ \\
\hline Skeletal Ni-P & 1.9 & 2.5 & 4.8 & 9.3 \\
Raney Ni & 0.7 & 1.5 & 2.9 & 4.4 \\
Skeletal Ni-La-P & 2.3 & 3.1 & 5.0 & 10.9 \\
\hline
\end{tabular}

Reaction conditions: 2.5 g catalyst, $50 \mathrm{ml} 30$ vol\% toluene in cyclohexane, $\mathrm{H}_{2}$ pressure $4 \mathrm{MPa}$, stirring at $29 \mathrm{r} / \mathrm{min}$, reaction time $1 \mathrm{~h}$. 
$\mathrm{Ni}-\mathrm{P}$ catalyst was more than twice that of the Raney Ni catalyst. A skeletal amorphous Ni-La-P alloy catalyst was subsequently prepared and its activity for the hydrogenation of toluene was also tested, with the results included in Table 4. The incorporation of La further improved the activity of the skeletal catalyst, possibly because of the improved thermal stability imparted by the La.

From the above results, it is evident that this new method of preparing the catalysts, involving the incorporation and subsequent removal of $\mathrm{Al}$, can remarkably increase both the specific surface area and the catalytic activity of the amorphous alloy. Because no time-consuming oxidation-reduction activation procedure was required, this preparation method works ideally to remove one of the main obstacles currently limiting the application of amorphous alloy catalysts in industry.

\section{The catalytic activities of skeletal amorphous $\mathrm{Ni}$ alloy catalysts}

\subsection{Hydrogenation of organic compounds on SRNA-1 and SRNA-2 catalysts}

\subsubsection{Hydrogenation of pharmaceutical intermediates on the SRNA-1 catalyst}

The trade name we have applied to the skeletal amorphous Ni-P alloy catalyst is SRNA-1. Table 5 shows the reaction conditions and results for the liquid-phase SRNA-1 hydrogenation of five pharmaceutical intermediates containing several potential hydrogenation sites, including phenyl rings, $\mathrm{C}=\mathrm{C}$ bonds, nitro groups and nitrile groups. The results show that the SRNA-1 catalyst exhibited higher activity than the Raney Ni catalyst. Under the same reaction conditions, the consumption of the SRNA-1 catalyst was $30 \%$ to $70 \%$ lower than that of the Raney Ni catalyst, showing that SRNA-1 is also more cost-effective. As a result of this improved performance, the current demand for the SRNA-1 catalyst for the hydrogenation of pharmaceutical intermediates is approximately $100 \mathrm{t}$ annually.
Table 6

Catalytic performance of the SRNA-2 catalyst and some commercial Raney Ni catalysts for glucose hydrogenation.

\begin{tabular}{lccrcr}
\hline Catalyst & $\begin{array}{c}T \\
(\mathrm{~K})\end{array}$ & $\begin{array}{c}P \\
(\mathrm{MPa})\end{array}$ & $\begin{array}{c}t \\
(\mathrm{~min})\end{array}$ & $\begin{array}{c}\text { Cat./glucose } \\
(53 \mathrm{wt} \% \text { in water })\end{array}$ & $\begin{array}{c}\text { Conversion } \\
(\%)\end{array}$ \\
\hline Raney Ni-1 & 408 & 6.5 & 70 & $1.6 \mathrm{~g} / 150 \mathrm{ml}$ & 99.1 \\
Raney Ni-2 & 393 & 4.76 & 300 & $2 \mathrm{~g} / 60 \mathrm{ml}$ & 99.2 \\
Raney Ni-3 & 408 & 7.0 & 70 & $1.1 \mathrm{~g} / 150 \mathrm{ml}$ & 94.3 \\
SRNA-2 & 408 & 5.0 & 70 & $1.1 \mathrm{~g} / 150 \mathrm{ml}$ & 100.0 \\
\hline
\end{tabular}

\subsubsection{Hydrogenation of glucose on the SRNA-2 catalyst}

The trade name of our skeletal amorphous Ni-B alloy catalyst is SRNA-2. This catalyst was prepared in a manner similar to the skeletal amorphous Ni-P alloy catalyst, with the exception of the replacement of the metalloid $\mathrm{P}$ by the metalloid $\mathrm{B}$. The data in Table 6 show that, compared with several commercial Raney Ni catalysts, the use of the SRNA-2 catalyst results in the complete conversion of glucose to sorbitol, while also allowing the application of lower $\mathrm{H}_{2}$ pressure, shorter reaction time and a lower catalyst-to-glucose ratio. The current demand for the SRNA-2 catalyst for the hydrogenation of glucose is around $200 \mathrm{t}$ annually, corresponding to a market share above $20 \%$.

\subsection{APR of ethylene glycol on the SRNA-3 catalyst [7]}

$\mathrm{H}_{2}$ is considered to be a potential source of clean energy because its use does not emit greenhouse gases, either during direct combustion or during the operation of a $\mathrm{H}_{2}$ fuel cell. The current methods for the industrial-scale production of $\mathrm{H}_{2}$ are primarily based on the use of non-renewable fossil fuels [8-11], and thus a process for obtaining $\mathrm{H}_{2}$ from renewable sources is highly desirable. Dumesic et al. [12,13] have demonstrated that $\mathrm{H}_{2}$ can be produced from sugars and sugar alcohols over either a Pt/ $\mathrm{Al}_{2} \mathrm{O}_{3}$ catalyst or a Sn-modified Raney Ni catalyst at temperatures near $500 \mathrm{~K}$ in a single-reactor aqueous phase reforming (APR) process.

\section{Table 5}

Comparison of the consumption of the SRNA-1 catalyst and Raney Ni.

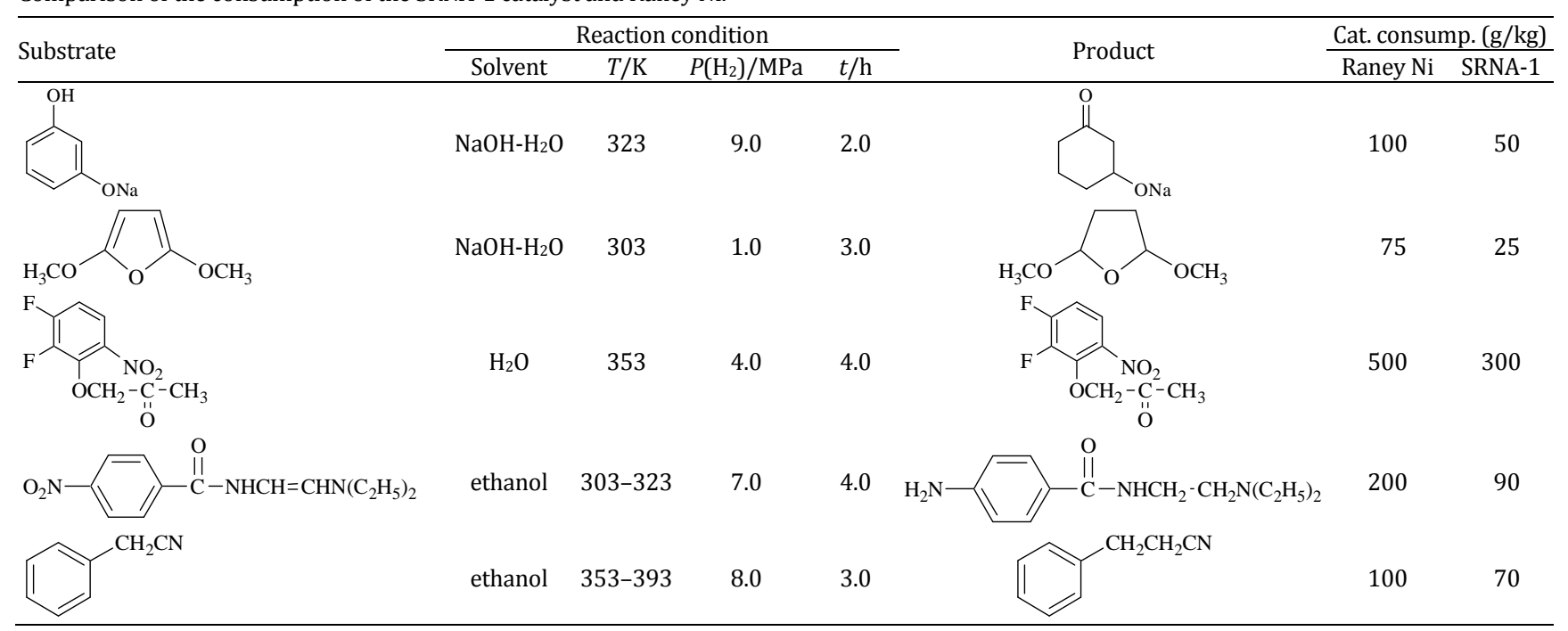


Table 7

Comparison of the catalytic behaviors of SRNA-3 catalyst and Raney Ni for APR of a $5 \mathrm{wt} \%$ ethylene glycol solution. Cited from Ref. [7] with permission from Elsevier.

\begin{tabular}{|c|c|c|c|c|}
\hline Item & $\begin{array}{c}\text { Raney Ni } \\
{[14]}\end{array}$ & $\mathrm{RQ} \mathrm{Ni}{ }^{\mathrm{a}}$ & $\begin{array}{c}\text { Raney Ni } \\
{[14]}\end{array}$ & $\mathrm{RQNi}^{\mathrm{a}}$ \\
\hline Temperature (K) & 498 & 498 & 538 & 538 \\
\hline Pressure (MPa) & 2.58 & 2.58 & 5.13 & 5.13 \\
\hline LHSV $\left(\mathrm{h}^{-1}\right)$ & 4.13 & 3.60 & 8.26 & 3.60 \\
\hline Conversion of $\mathrm{C}$ to gas (\%) & 97 & 92 & 104 & 102 \\
\hline $\mathrm{H}_{2}$ selectivity $(\%)$ & 35 & 35 & 28 & 21 \\
\hline Alkane selectivity (\%) & 44 & 47 & 47 & 59 \\
\hline \multicolumn{5}{|l|}{ Gas products (mol\%) } \\
\hline $\mathrm{H}_{2}$ & 47.6 & 47.4 & 41.4 & 34.9 \\
\hline $\mathrm{CO}_{2}$ & 30.4 & 30.8 & 31.9 & 27.2 \\
\hline $\mathrm{CO}$ & 0.02 & n.d.b & 0.03 & n.d.b \\
\hline Methane & 20.7 & 22.8 & 25.6 & 36.4 \\
\hline Ethane & 0.97 & 1.12 & 0.92 & 1.43 \\
\hline Propane & 0.28 & 0.23 & 0.18 & 0.15 \\
\hline Butane & 0.02 & 0.00 & 0.01 & 0.00 \\
\hline \multicolumn{5}{|c|}{ Liquid products (mol\%, excluding unreacted EG) } \\
\hline Methanol & 10.2 & 85.1 & 34.3 & 95.1 \\
\hline Ethanol & 48.3 & 12.9 & 2.5 & 3.5 \\
\hline Acetic acid & 30.2 & 0.0 & 63.2 & 0.0 \\
\hline Acetaldehyde & 7.3 & 0.0 & 0.0 & 0.0 \\
\hline Glycolaldehyde & 4.0 & 0.0 & 0.0 & 0.0 \\
\hline 2-Propanol & 0.0 & 0.2 & 0.0 & 0.2 \\
\hline Acetone & 0.0 & 1.8 & 0.0 & 1.2 \\
\hline
\end{tabular}

a 0.5 g of catalyst.

b Below the detection limit.

\subsubsection{Comparison between the SRNA-3 catalyst and Raney Ni}

SRNA-3 is the trade name of a skeletal amorphous Ni catalyst which has a lower atomic coordination number and a bulk composition with an atomic ratio of $\mathrm{Ni}_{84} \mathrm{Al}_{16}$. Because of the absence of a metalloid, the SRNA-3 catalyst is partly crystalline. Table 7 compiles the $\mathrm{H}_{2}$ and alkane selectivities and gas and liquid product distributions at 498 and $538 \mathrm{~K}$ over the SRNA-3 and Raney Ni catalysts [14]. SRNA-3 exhibited comparable or lower $\mathrm{H}_{2}$ selectivity and higher alkane selectivity as compared with the Raney Ni catalyst. However, SRNA-3 produced less CO in the effluent gas, which is especially significant when considering applications in the field of $\mathrm{H}_{2}$ fuel cells, because the cell anode materials are usually vulnerable to CO poisoning [15].

\subsubsection{The promoting effect of Sn on the SRNA-3 catalyst}

Figure 3 shows the trends in $\mathrm{H}_{2}$ and alkane selectivities as increasing amounts of $\mathrm{Sn}$ are incorporated into the SRNA-3 catalyst. As can be seen, the selectivity of the catalyst for $\mathrm{H}_{2}$ increased when the $\mathrm{Sn}$ content was increased, with the $\mathrm{H}_{2}$ selectivity exceeding $90 \%$ at $\mathrm{Sn} / \mathrm{Ni}$ molar ratios above $4.4 \%$. The alkane selectivity showed the opposite trend to that of $\mathrm{H}_{2}$. At a $\mathrm{Sn} / \mathrm{Ni}$ ratio of $15.7 \%$, the alkane selectivity was less than $1 \%$, whereas the $\mathrm{H}_{2}$ selectivity reached as high as $98 \%$. Kinetic data suggest that the addition of Sn not only decreases the turnover frequencies (TOF) for the alkanes, but also steadily increases the TOFs for $\mathrm{H}_{2}$ and $\mathrm{CO}_{2}$, thus leading to higher selectivity for $\mathrm{H}_{2}$.

3.3. Chemoselective hydrogenation of 2-ethylanthraquinone (eAQ) on the SRNA-5 catalyst [16]

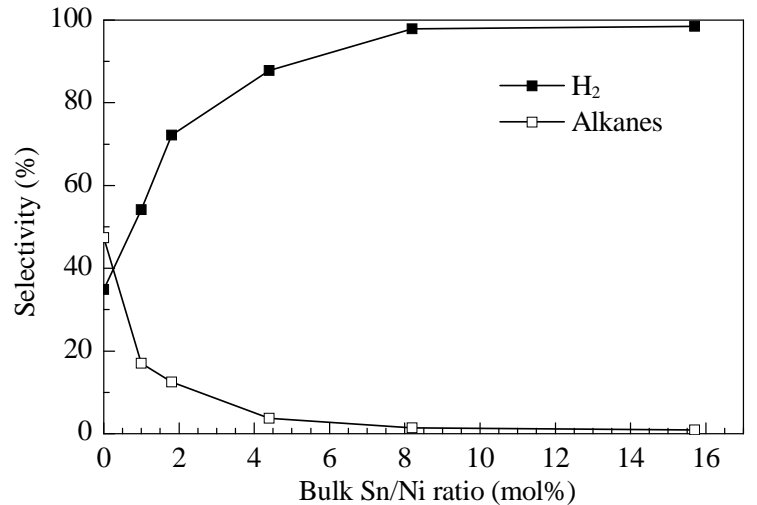

Fig. 3. Effect of $\mathrm{Sn} / \mathrm{Ni}$ molar ratios in Sn-modified SRNA-3 catalysts on $\mathrm{H}_{2}$ and alkane selectivities during APR of ethylene glycol. Reaction conditions: 0.5 g catalyst, $5 \mathrm{wt} \%$ ethylene glycol aqueous solution, LHSV $3.60 \mathrm{~h}^{-1}$, temperature $498 \mathrm{~K}$, pressure $2.58 \mathrm{MPa}$. Cited from Ref. [7] with permission from Elsevier.

The hydrogenation of eAQ is a key step in the industrial production of $\mathrm{H}_{2} \mathrm{O}_{2}$ [17]. As shown in Scheme 1, the hydrogenation produces 2-ethylanthrahydroquinone $\left(\mathrm{eAQH}_{2}\right)$ and 2-ethyltetrahydroanthrahydroquinone $\left(\mathrm{H}_{4} \mathrm{eAQH} 2\right)$, the "active quinones" [18], which can then be oxidized to produce $\mathrm{H}_{2} \mathrm{O}_{2}$. Other more fully hydrogenated and hydrogenolysis products (degradation products) are not desirable, because they can neither produce $\mathrm{H}_{2} \mathrm{O}_{2}$ nor be regenerated, which leads to the loss of expensive eAQ. In industry, Pd catalysts are used in eAQ hydrogenation because of their high selectivity for active quinones [17]. These Pd catalysts, however, are highly expensive. We therefore developed the SRNA-5 catalyst for the chemoselective hydrogenation of eAQ. SRNA-5 is the trade name of a skeletal amorphous $\mathrm{Ni}$ catalyst promoted by $\mathrm{Cr}$ and $\mathrm{Fe}$, with an atomic ratio of $\mathrm{Ni}_{74.6} \mathrm{Fe}_{2.4} \mathrm{Cr}_{4.3} \mathrm{Al}_{18.6}$.

Figure 4(a) shows the percent yield of $\mathrm{H}_{2} \mathrm{O}_{2}$ as a function of time for both catalysts. Over the SRNA- 5 catalyst, the yield of $\mathrm{H}_{2} \mathrm{O}_{2}$ initially increases and then levels off, with $X(X=$ $n^{t}{ }_{\mathrm{H} 2 \mathrm{O} 2} / n^{0} \mathrm{eAQ}_{\mathrm{Q}} \times 100 \%$, which also represents the selectivity for active quinones) plateauing at approximately $97 \%$. In comparison, the yield of $\mathrm{H}_{2} \mathrm{O}_{2}$ over Raney $\mathrm{Ni}$ reaches a maximum of only $67 \%$ and drops after prolonged reaction times. These results clearly demonstrate the higher selectivity of the SRNA-5 catalyst in the hydrogenation of eAQ to active quinones, as

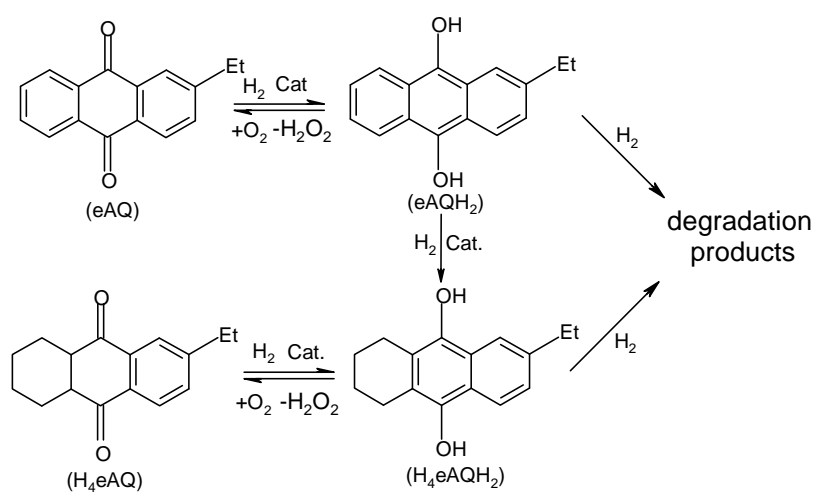

Scheme 1. Reaction products in the hydrogenation of eAQ. Cited from Ref. [16] with permission from Elsevier. 


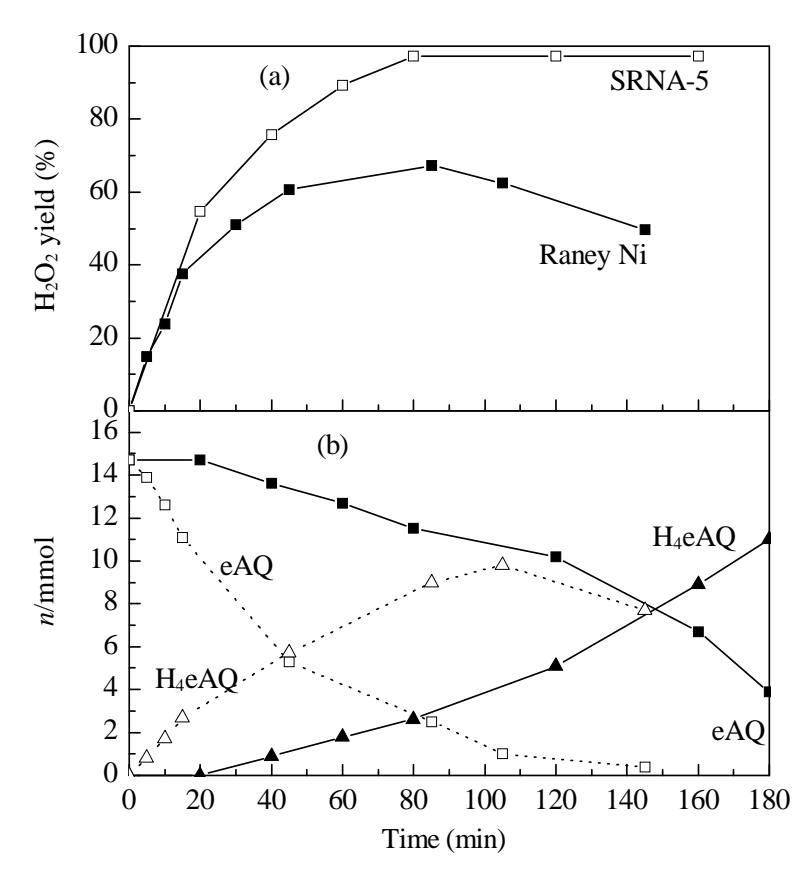

Fig. 4. $\mathrm{H}_{2} \mathrm{O}_{2}$ yield (a) and the evolution of eAQ and $\mathrm{H}_{4} \mathrm{eAQ}$ (b) over the SRNA-5 and Raney Ni catalysts as a function of the reaction time. In (b), solid lines are for SRNA-5 and dotted lines for Raney Ni. Cited from Ref. [16] with permission from Elsevier.

compared with the conventional Raney Ni catalyst.

In order to gain further insight into variations in the selectivity of these two catalysts, the outputs of both eAQ and $\mathrm{H}_{4} \mathrm{eAQ}$ were monitored and plotted in Fig. 4(b). It should be noted that the plotted values for eAQ in Fig. 4(b) denotes the sum total of unreacted eAQ and eAQ hydrogenated to $\mathrm{eAQH}_{2}$, while the values for $\mathrm{H}_{4} \mathrm{eAQ}$ equal the quantity of $\mathrm{H}_{4} \mathrm{eAQH}$, as can be seen by referencing the reduction-oxidation cycles shown in Scheme 1. Using the SRNA-5 catalyst, no $\mathrm{H}_{4} \mathrm{eAQ}$ was generated during the first $20 \mathrm{~min}$, which is indicative of the catalyst's high selectivity for $\mathrm{eAQH}_{2}$. In contrast, when using Raney $\mathrm{Ni}, \mathrm{H}_{4} \mathrm{eAQ}$ was produced as soon as the hydrogenation commenced. Based on gas chromatography-mass spectrometry (GC-MS) analysis, $\mathrm{H}_{8} \mathrm{eAQH} 2$ was also immediately generated over Raney Ni. We can therefore conclude that the SRNA- 5 catalyst exhibits higher selectivity than Raney Ni for carbonyl group hydrogenation in the presence of an aromatic ring, thus leading to higher yields of $\mathrm{H}_{2} \mathrm{O}_{2}$ and lower consumption of $\mathrm{H}_{2}$ and expensive eAQ, which is highly preferred for an industrial process.

\section{Adsorptive desulfurization of transportation fuels on skeletal amorphous $\mathrm{Ni}$ alloys}

Most transportation fuels currently in use contain 100 to $1000 \mu \mathrm{g} / \mathrm{g}$ of organosulfur compounds. These S-containing molecules not only react with oxygen during combustion to produce the $\mathrm{SO}_{x}$ species which lead to acid rain [19], but also act to poison catalytic converters and thus create additional pollutants as well $[20,21]$. The EU and United States have both announced plans to reduce the allowable $\mathrm{S}$ content in gasoline and diesel fuels to $10 \mu \mathrm{g} / \mathrm{g}$ [22-24]. In addition, for fuel cells using gasoline as feedstock, a S content below $0.2 \mu \mathrm{g} / \mathrm{g}$ is pre- ferred [25]. The desulfurization of transportation fuels by adsorption is a promising means to allow such fuels to meet these stringent environmental regulations [25-27]. Adsorptive desulfurization has the benefits of low investment cost and simple technology, minimal reduction in both the yield and octane number of gasoline, no consumption of $\mathrm{H}_{2}$ and no need for extreme reaction conditions such as high temperature and pressure. To date, however, the use of metallic adsorbents in this process has not attracted significant attention, even though Raney Ni has seen widespread use in the desulfurization of organic and organometallic compounds [28-30].

\subsection{In situ XPS study on the desulfurization of thiophene over SRNA-3 [31]}

\subsubsection{Adsorption and dissociation of thiophene}

Following the addition of thiophene to SRNA-3 at $103 \mathrm{~K}$, the $\mathrm{S} 2 p_{3 / 2}$ binding energy (BE) of physisorbed thiophene at 165.1 $\mathrm{eV}$ was identified during subsequent XPS analysis [32]. After heating to $173 \mathrm{~K}$, about one half of the physisorbed thiophene was desorbed, although only about $17 \%$ of the thiophene retained on the catalyst surface underwent sulfur abstraction, while the rest remained intact. Further annealing to $273 \mathrm{~K}$ induced scission of the $\mathrm{C}-\mathrm{S}$ bonds of the residual thiophene and the surface concentration of atomic $S$ reached a maximum and the formation of nickel sulfide commenced. At $473 \mathrm{~K}$, there was only one doublet peak located between 160 and $165 \mathrm{eV}$, due to sulfur in the form of nickel sulfide $[33,34]$. The total sulfur intensity remained constant from 173 to $473 \mathrm{~K}$.

On Raney $\mathrm{Ni}$, thiophene in direct contact with the metallic $\mathrm{Ni}$ readily decomposes upon thermal annealing to give carbonaceous species and atomic sulfur. The $\mathrm{C}-\mathrm{S}$ bonds of thiophene undergo scission at approximately $173 \mathrm{~K}$ on Raney $\mathrm{Ni}$, close to the scission temperature of approximately $150 \mathrm{~K}$ observed on a $\mathrm{Ni}(111)$ surface [35]. It is consistent with experimental observations that the (111) diffraction peak is the dominant feature in the diffractogram of Raney Ni [36]. On the SRNA-3 alloy, however, most chemisorbed thiophene remained intact at 173 $\mathrm{K}$ and did not dissociate until $273 \mathrm{~K}$, a temperature significant higher than the dissociation temperatures observed on Ni single crystals and Raney Ni.

\subsubsection{Interpretation of differences in surface chemistry}

We determined that the unit-cell dimension in SRNA-3 alloy is $0.3548 \mathrm{~nm}$, which is significantly larger than in either Raney $\mathrm{Ni}$ or crystalline Ni [36]. This difference in unit cells may be attributed to the effect of quenching, which may cause atoms in the $\mathrm{Ni}-\mathrm{Al}$ alloy to deviate from their equilibrium positions. It is known that the dissociation of an activated molecule is generally possible only when there is a good match between the interatomic distances in the molecule and the atomic arrangement of the surface metal atoms [37]. The increased Ni-Ni distance in the SRNA-3 alloy may therefore not be conducive to the scission of $\mathrm{C}-\mathrm{S}$ bonds. The melt-quenching technique thus presents new possibilities for the design of metallic adsorbents with tunable bonding strengths towards thiophene or thiophenic compounds. As an example, by further increasing the 


\section{Table 8}

Adsorptive desulfurization of gasoline by SRNA-3 alloy. Cited from Ref. [39].

\begin{tabular}{|c|c|c|c|c|c|c|}
\hline \multirow{2}{*}{ Gasoline } & \multirow{2}{*}{$\begin{array}{l}\text { Amount of } \\
\text { adsorbent } \\
\text { (g) }\end{array}$} & \multirow{2}{*}{$\begin{array}{c}T \\
(\mathrm{~K})\end{array}$} & \multirow{2}{*}{$\begin{array}{c}\text { Residence } \\
\text { time } \\
\text { (min) }\end{array}$} & \multicolumn{2}{|c|}{$S\left(10^{-6}\right)$} & \multirow{2}{*}{$\begin{array}{c}\text { Desulf. } \\
\text { ratio } \\
(\mathrm{wt} \%) \\
\end{array}$} \\
\hline & & & & In feed & In product & \\
\hline Feed-1 & 40 & 293 & 5 & 1800 & 470 & 73.9 \\
\hline Feed-2 & 10 & 333 & 5 & 335 & 17 & 94.9 \\
\hline Feed-3 & 20 & 313 & 10 & 265 & $<1$ & $>99.6$ \\
\hline
\end{tabular}

Adsorption conditions: $250 \mathrm{ml}$ gasoline, alloys particle diameters $60-80$ $\mu \mathrm{m}$, stirring rate $280 \mathrm{r} / \mathrm{min}$, blanketed by $\mathrm{N}_{2}$ at ambient pressure.

quenching rate it is possible to obtain $\mathrm{Ni}$ adsorbent on which thiophene does not decompose even at room temperature. The intact thiophene molecules can consequently be removed via supercritical $\mathrm{CO}_{2}$ extraction [38], thus simplifying the regeneration of the $\mathrm{Ni}$ adsorbent.

\subsection{Adsorptive desulfurization of gasoline and diesel [39,40]}

\subsubsection{Adsorptive desulfurization of gasoline}

Three different gasoline feedstocks were used in these studies. Feed-1 was a full-range gasoline derived from fluidized catalytic cracking (FCC), with a density of $0.7200 \mathrm{~g} / \mathrm{cm}^{3}$ and a S content of $1800 \mu \mathrm{g} / \mathrm{g}$. Feed-2 was a heavy fraction of hydro-treated FCC gasoline, with a density of $0.7800 \mathrm{~g} / \mathrm{cm}^{3}$ and a $\mathrm{S}$ content of $335 \mu \mathrm{g} / \mathrm{g}$. Feed-3 was a light fraction of FCC gasoline, with a density of $0.6600 \mathrm{~g} / \mathrm{cm}^{3}$ and a S content of 265 $\mu \mathrm{g} / \mathrm{g}$. The $\mathrm{S}$ content in gasoline after adsorption by the SRNA-3 alloy in a slurry-bed reactor was measured by a microcoulometric technique. The results summarized in Table 8 show that the $\mathrm{S}$ content in the resulting product can be readily controlled by varying the adsorbent/gasoline ratio and the adsorption conditions. The S contents of Feed- 1 and Feed- 2 were decreased to below $500 \mu \mathrm{g} / \mathrm{g}$ and $50 \mu \mathrm{g} / \mathrm{g}$, respectively, which would meet Chinese gasoline regulations. In the case of Feed-3, when using $20 \mathrm{~g}$ of the SRNA-3 alloy as the adsorbent at an adsorption temperature of $313 \mathrm{~K}$ and a residence time of 10 min, less than $1 \mu \mathrm{g} / \mathrm{g}$ of $\mathrm{S}$ was left in the gasoline, demonstrating that SRNA-3 alloy is a promising adsorbent for the production S-free gasoline under mild adsorption conditions.

\subsubsection{Adsorptive desulfurization of diesel}

Although adsorptive desulfurization over alloys is also applicable to straight-run diesel, FCC diesel or coker diesel, wherein the S content may range from 500 to $10000 \mu \mathrm{g} / \mathrm{g}$, considering that the majority of the organic sulfides in diesel (in-

\section{Table 9}

Adsorptive desulfurization of diesel by SRNA-3 alloy. Cited from Ref. [40].

\begin{tabular}{cc}
\hline Adsorption temperature $(\mathrm{K})$ & S content after adsorption $\left(10^{-6}\right)$ \\
\hline 293 & 20 \\
313 & 15 \\
333 & 10 \\
353 & 9 \\
\hline
\end{tabular}

Adsorption conditions: $100 \mathrm{ml}$ diesel, $1 \mathrm{~g}$ alloy with particle diameter of 60-80 $\mu \mathrm{m}$, stirring rate $300 \mathrm{r} / \mathrm{min}$, adsorption time $10 \mathrm{~min}$, blanketed by $\mathrm{N}_{2}$ at ambient pressure. Sulfur in the raw feed is $70 \times 10^{-6}$. cluding thiols, thioethers, and thiophenes) can be readily removed by hydrodesulfurization (HDS), we used HDS diesel for adsorptive desulfurization testing, for economical and practical purposes. Heterocyclic sulfur compounds such as benzothiophenes, dibenzothiophenes, and their derivatives are difficult to remove by the conventional HDS process, and so we monitored for these compounds using a gas chromatograph equipped with an atomic emission detector (GC-AED). The diesel sample had a density of $0.8400 \mathrm{~g} / \mathrm{cm}^{3}$ and a distillation range of 477-644 $\mathrm{K}$. The $\mathrm{S}$ content in the diesel after adsorption in a slurry-bed reactor was determined by GC-AED and is given in Table 9. From these results, we see that higher adsorption temperatures produce lower $\mathrm{S}$ content following adsorption.

\section{Examples of commercial applications of skeletal amorphous $\mathrm{Ni}$ alloy catalysts}

A $30 \mathrm{t}$ per year prototype unit for the manufacture of SRNA catalysts was commissioned in 1993, with the aim of both improving the production technology and reducing costs. The melt-quenching method was used to manufacture amorphous alloys in this facility and specially designed equipment was required, since the liquid $\mathrm{Ni}-\mathrm{Al}$ alloy is very viscous, has a high melting point and is susceptible to oxidation. This commercial demonstration unit was primarily used to optimize the design of the graphite crucible, graphite nozzles and copper roller used in the melt cooling process. A scaled-up $100 \mathrm{t}$ per year production facility for the manufacture of SRNA catalysts was constructed in 1995. A unique thermal treatment procedure was developed at that time which resulted in SRNA catalysts with improved amorphism and enhanced hydrogenation activity. The process flow associated with the manufacture of SRNA catalysts in this facility incorporated the regeneration and utilization of sodium meta-aluminate by collecting the spent mother liquor and wash water to provide raw materials for the production of alumina or zeolite. This measure not only avoids environmental pollution, but also allows for the maximized utilization of aluminum feedstocks as well as reduction in the production costs of the SRNA catalysts.

\subsection{The commercial application of SRNA-4 in the purification of caprolactam [41]}

The post-refining of caprolactam aims to saturate any unsaturated impurities via hydrogenation, to differentiate their physical properties from those of caprolactam. The existing technology generally utilizes the Raney Ni catalyst in a hydrogenation process consisting of a series of two $10 \mathrm{~m}^{3}$ kettle-type reactors operating at $0.7 \mathrm{MPa}$ and $363 \mathrm{~K}$. Impurities are saturated through hydrogenation prior to being separated via distillation, which ensures high quality in nylon-6 made from the resulting caprolactam. The product's PM value is widely used as an indicator of the quality (that is, the impurity content) of the caprolactam such that the higher the PM value is, the lower the impurity content. The PM value of premium-quality caprolactam should be above $30000 \mathrm{~s}$, although the value of caprolactam manufactured by existing technology is generally 20000 
s, a level at which it cannot be used to fabricate commercial products by high-speed spinning. Based on the distinct advantages of the SRNA-4 catalyst over the Raney Ni catalyst in bench and pilot tests, the catalyst was successfully substituted for Raney Ni catalyst in a commercial caprolactam production process in 1998. Upon the employment of the SRNA-4 catalyst, the consumption of the catalyst was reduced from 0.21 to 0.18 $\mathrm{kg} / \mathrm{t}$, resulting in a total catalyst consumption decrease of $14 \%$. The demand for SRNA-4 catalyst for the purification of caprolactam is currently around $150 \mathrm{t}$ annually, and its market share is above $80 \%$.

\subsection{CO methanation in the hydrogenation of benzoic acid to cyclohexanecarboxylic acid [42]}

The synthetic process used commercially for the production of caprolactam from toluene, the SNIA Viscosa process, consists primarily of the oxidation of toluene to benzoic acid, the hydrogenation of benzoic acid to cyclohexanecarboxylic acid (CCA) and the amidation of CCA to caprolactam. In this process, the hydrogenation of benzoic acid is carried out in a series of continuously stirred reactor tanks over a $5 \% \mathrm{Pd} / \mathrm{C}$ catalyst. This method, however, suffers from a number of shortcomings that lead to inefficient operation of the equipment and excessive consumption of the expensive $\mathrm{Pd} / \mathrm{C}$ catalyst. In addition, recycled $\mathrm{Pd} / \mathrm{C}$ catalyst exhibits catalytic activity only $1 / 6$ to $1 / 5$ that of fresh catalyst. Among the factors contributing to the deactivation of the catalyst, CO released from the decarboxylation of CCA is regarded as the most important, because even a trace amount of $\mathrm{CO}$ is sufficient to deactivate Pd. Because the SRNA- 5 catalyst is effective in eliminating $\mathrm{CO}$ by methanation, and the presence of chromium in this catalyst can improve its acid resistance, we introduced its use into the industrial process for the hydrogenation of benzoic acid. Simultaneously, the design of the production equipment and flow process were also improved, because the use of SRNA-5 introduced problems associated with recycling and separating the catalyst.

\subsubsection{The promoting effect of SRNA-5 catalyst in a conventional industrial unit}

Following the incorporation of SRNA-5 into a conventional industrial process unit, the concentration of $\mathrm{CO}$ in the reaction system was reduced from approximately $300 \mu \mathrm{g} / \mathrm{g}$ to about $100 \mu \mathrm{g} / \mathrm{g}$. Increasing the amount of SRNA-5 also resulted in steady increases in the activity of the recycled $\mathrm{Pd} / \mathrm{C}$ catalyst. As a result, the amount of CCA produced per $\mathrm{kg} \mathrm{Pd}$ increased from $35 \mathrm{t}$ using the recycled $\mathrm{Pd} / \mathrm{C}$ catalyst alone to $50 \mathrm{t}$ using a combination of $0.8 \mathrm{wt} \%$ SRNA-5 in conjunction with the recycled $\mathrm{Pd} / \mathrm{C}$. In addition, consumption of the fresh $5 \% \mathrm{Pd} / \mathrm{C}$ catalyst during sustained hydrogenation activity was reduced by $46 \%$.

\subsubsection{Modification of the conventional industrial process}

Because the centrifuge separator employed in the traditional process was originally designed for the separation of the $\mathrm{Pd} / \mathrm{C}$ catalyst, and because the SRNA- 5 catalyst has a much higher density, we found that the existing unit was not sufficient to recycle SRNA-5. As a result, there were several hundred $\mu \mathrm{g} / \mathrm{g}$ of Ni left in the spent Pd/C catalyst, which lengthened the incineration time required to treat the spent $\mathrm{Pd} / \mathrm{C}$ catalyst to two weeks, greatly increasing the cost associated with keeping spare stock of fresh Pd/C catalyst on hand. Process improvements were therefore necessary to solve the recycling and separation problems caused by the introduction of the SRNA-5 catalyst.

To fully utilize the beneficial effects of SRNA-5 in this process, we modified the existing catalyst separation unit by incorporating a hydraulic cyclone after the hydrogenation reactor and a novel magnetic separator after the evaporator. A schematic of the modified process for the hydrogenation of benzoic acid is presented in Fig. 5. In this modified process, the hydraulic cyclone recycles the majority of the SRNA-5 as well as the spent Pd/C catalyst to tank VE203, which reduces the load on the centrifuge separator. When the hydraulic cyclone was first employed in the separation unit, the level of residual $\mathrm{Ni}$ in the spent Pd/C catalyst was reduced substantially, to $10 \%$ of its

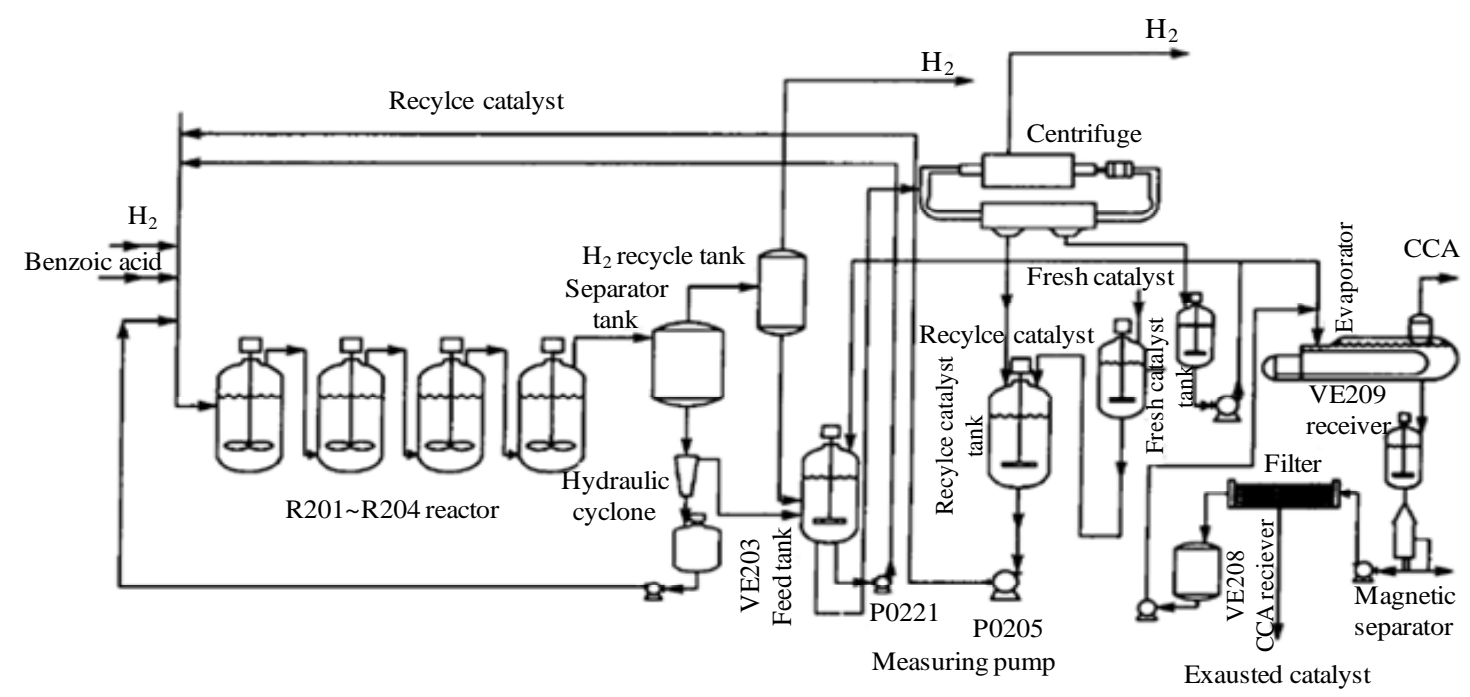

Fig. 5. Schematic diagram of the modified industrial process for the hydrogenation of benzoic acid. Cited from Ref. [42] with permission from American Institute of Chemical Engineers. 
level before the use of the cyclone. The incineration time required to treat the spent $\mathrm{Pd} / \mathrm{C}$ catalyst was accordingly shortened to 7-8 $\mathrm{d}$.

Because the SRNA-5 catalyst is ferromagnetic, while the $\mathrm{Pd} / \mathrm{C}$ catalyst is not magnetizable, we designed a permanent magnet-based separator operating in the magnetic condensation mode to further isolate the SRNA-5 catalyst from the Pd/C catalyst. We found that the concentration of $\mathrm{Ni}$ remaining in the spent $\mathrm{Pd} / \mathrm{C}$ catalyst after using this three-step separation strategy was only $1 / 4$ to $1 / 3$ of that which remained when using a combination of the hydraulic cyclone and the centrifuge separator. The incineration time for the spent $\mathrm{Pd} / \mathrm{C}$ catalyst was further shortened to $4-5 \mathrm{~d}$, which is close to that required without the addition of the SRNA- 5 catalyst. Moreover, because of the much more thorough recycling of the SRNA-5 catalyst, the amount of CCA produced per kg Pd was increased by approximately $20 \%$ as compared with using the centrifuge separator alone. The consumption of fresh $\mathrm{Pd} / \mathrm{C}$ catalyst was reduced by about $50 \%$, while the purity of CCA was increased by $0.5 \%$, demonstrating the superiority of the modified process for the hydrogenation of benzoic acid. Moreover, the modified industrial unit exhibited greater temperature and pressure stability, meaning that fewer ongoing adjustments of these parameters were required. Finally, the prolonged lifetime of the $\mathrm{Pd} / \mathrm{C}$ catalyst allowed less frequent recovery of the spent $\mathrm{Pd} / \mathrm{C}$ catalyst, thus improving the process efficiency. This improved design concept and separation strategy may also present opportunities for the improvement of other industrial hydrogenation processes which may have issues with CO poisoning of catalysts.

\section{Conclusions}

This paper presents an overview of our research efforts concerning the innovation of amorphous $\mathrm{Ni}$ alloy catalysts prepared by the melt-quenching technique and related chemical engineering processes. The inherent disadvantages of amorphous alloy catalysts, in terms of small specific surface area and low thermal stability, have been successfully mitigated, which allows the possibility of developing these materials into practical catalysts with improved performance, as substitutes for the Raney Ni catalyst. Based on these endeavors, we have achieved the first successful commercial applications of skeletal amorphous Ni alloy catalysts in the international arena. Our work to date has been primarily limited to the study of Ni-based amorphous alloy catalysts, and there are many potential applications for these catalysts which have not yet been fully explored. Further investigations may include the development of skeletal amorphous alloy catalysts based on other metals such as $\mathrm{Co}, \mathrm{Fe}, \mathrm{Cu}$ or $\mathrm{Ru}$, which may find important applications in selective hydrogenation, CO hydrogenation, ammonia synthesis, biomass conversion, and other industrial processes. Nevertheless, our work forms a preliminary basis for the understanding of the physicochemical properties and catalytic behaviors of new skeletal amorphous alloy catalysts. We believe that more comprehensive and in-depth investigations in this field will undoubtedly improve the practical appli- cations and theoretical understanding of skeletal amorphous alloy catalysts, with significant benefits to the fine chemical and petrochemical industry.

\section{Acknowledgments}

The authors would like to thank Professor Enze Min, since the contents of this paper are primarily based on the $\mathrm{Ph}$. $\mathrm{D}$ theses of the authors under his supervision and guidance.

\section{References}

[1] Seymour R, Montgomery S. Murray Raney-Pioneer Catalyst Producer. In: Davis B H, Hettinger W P eds. Heterogeneous Catalysis-Selected American Histories, Vol 222. Washington: American Chemical Society, 1983. 491

[2] Yokoyama A, Komiyama H, Inoue H, Masumoto T, Kimura H M. J Catal, 1981, 68: 355

[3] Zong B N. [PhD Dissertation]. Beijing: Research Institute of Petroleum Processing, 1991

[4] Chen H S. Acta Metall, 1976, 24: 153

[5] Chen H S. Appl Phys Lett, 1976, 29: 12

[6] Mu X H, Zong B N, Min E Z, Wang X, Wang Y, Zhang X X, Shu X T. US Patent 6368996B1. 2002

[7] Xie F Z, Chu X W, Hu H R, Qiao M H, Yan S R, Zhu Y L, He H Y, Fan K N, Li H X, Zong B N, Zhang X X. J Catal, 2006, 241: 211

[8] Clarke S H, Dicks A L, Pointon K, Smith T A, Swann A. Catal Today, 1997, 38: 411

[9] Rath L K, Longanbach J R. Energy Sources, 1991, 13: 443

[10] Rostrup-Nielsen J R. Steam Reforming Catalysts. Copenhagen: Danish Technical Press, 1975

[11] Rostrup-Nielsen J R. Phys Chem Chem Phys, 2001, 3: 283

[12] Cortright R D, Davda R R, Dumesic J A. Nature, 2002, 418: 964

[13] Huber G W, Shabaker J W, Dumesic J A. Science, 2003, 300: 2075

[14] Shabaker J W, Huber G W, Dumesic J A. J Catal, 2004, 222: 180

[15] Lemons R A.J Power Sources, 1990, 29: 251

[16] Liu B, Qiao M H, Deng J F, Fan K N, Zhang X X, Zong B N. J Catal, 2001, 204: 512

[17] Kroschwitz J I, Howe-Grant M. Kirk-Othmer Encyclopedia of Chemical Technology. 4th Ed, Vol. 13. New York: John Wiley \& Sons, 1995.961

[18] Roberts J D, Caserio M C. Basic Principles of Organic Chemistry. California: W. A. Benjamin, 1964

[19] Stern A C, Boubel R W, Turner D B, Fox D L. Fundamentals of Air Pollution. 2nd Ed. New York: Academic Press, 1984

[20] Bartholomew C H, Agrawal P K, Katzer J R. Adv Catal, 1982, 31: 135

[21] Oudar J. Catal Rev-Sci Eng, 1980, 22: 171

[22] Plantenga F L, Leliveld R G. Appl Catal A, 2003, 248: 1

[23] Rossini S. Catal Today, 2003, 77: 467

[24] Babich I V, Moulijin J A. Fuel, 2003, 82: 607

[25] Hernández-Maldonado A J, Yang R T. Ind Eng Chem Res, 2004, 43: 1081

[26] Yang R T. Adsorbents: Fundamentals and Applications. New York: Wiley, 2003

[27] Yang R T, Hernández-Maldonado A J, Yang F H. Science, 2003, 301: 79

[28] Hurd C D, Runder B. J Am Chem Soc, 1951, 73: 5157

[29] Pizey J S. Synthetic Reagents, Vol 2. New York: Wiley, 1974

[30] Spera M L, Harman W D. J Am Chem Soc, 1997, 119: 8843

[31] Hu H R, Qiao M H, Xie F Z, Fan K N, Lei H, Tan D L, Bao X H, Lin H L, 


\section{Graphical Abstract}

Chin. J. Catal., 2013, 34: 828-837 doi: 10.1016/S1872-2067(11)60486-5

Research, development, and application of amorphous nickel alloy catalysts prepared by melt-quenching

ZONG Baoning*, MU Xuhong, ZHANG Xiaoxin, MENG Xiangkun, QIAO Minghua Research Institute of Petroleum Processing;

Fudan University

Transforming crystalline Raney $\mathrm{Ni}$ into an amorphous structure by the application of a melt-quenching technique can significantly enhance the material's catalysis of hydrogenation reactions.

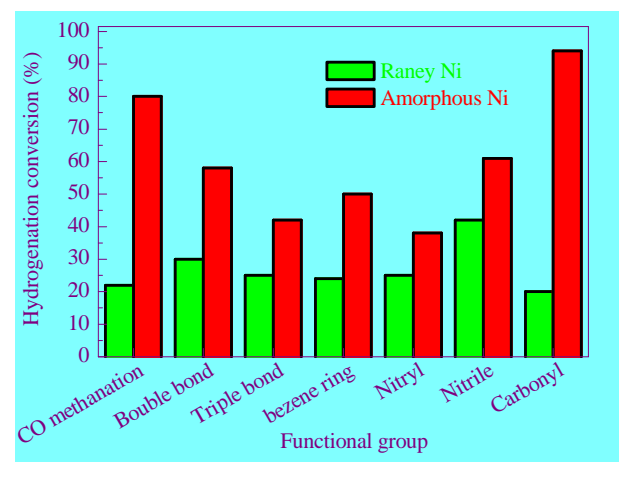

Zong B N, Zhang X X. J Phys Chem B, 2005, 109: 5186

[32] Jirsak T, Dvorak J, Rodriguez J A. J Phys Chem B, 1999, 103: 5550

[33] Handbook of X-ray Photoelectron Spectroscopy. Perkin Elmer Corporation, 1992

[34] Barrio V L, Arias P L, Cambra J F, Güemez M B, Campos-Martin J M, Pawelec B, Fierro J L G. Appl Catal A, 2003, 248: 211

[35] Schoofs G R, Preston R E, Benziger J B. Langmuir, 1985, 1: 313

[36] Hu H R, Qiao M H, Wang S, Fan K N, Li H X, Zong B N, Zhang X X.J Catal, 2004, 221: 612

[37] Balandin A A. Z Phys Chem, 1929, 132: 289
[38] Vradman L, Herskowitz M, Korin E, Wisniak J. Ind Eng Chem Res, 2001, 40: 1589

[39] Zong B N, Meng X K, Lin H L, Zhang X X, Mu X H, Min E Z. US Patent 6875340B2. 2005

[40] Zhang X X, Zong B N, Meng X K, Wang X, Mu X H, Min E Z. CN Patent 1179021C. 2004

[41] Meng X K, Mu X H, Zong B N, Min E Z, Zhu Z H, Fu S B, Luo Y B. Catal Today, 2003, 79-80: 21

[42] Zong B N, Zhang X X, Qiao M H. AIChE J, 2009, 55: 192

\section{急冷非晶态镍合金催化剂的研究开发和工业应用}

宗保宁 ${ }^{\mathrm{a},{ }^{*}}$ ，慕旭宏 ${ }^{\mathrm{a}}$, 张晓昕 ${ }^{\mathrm{a}}$, 孟祥枋 ${ }^{\mathrm{a}}$, 乔明华 ${ }^{\mathrm{b}}$

$\mathrm{a}$ 中国石油化工股份有限公司石油化工科学研究院, 催化材料和反应工程国家重点实验室, 北京 100083

$\mathrm{b}$ 复旦大学化学系, 上海市分子催化和功能材料重点实验室, 上海 200433

摘要: Raney Ni催化剂是石油化学工业用量最大的催化剂之一, 通过急冷技术将其晶态结构转变为非晶态结构, 能够提高加氢活 性. 但非晶态合金热稳定性差、比表面积小限制了这类催化材料的工业应用. 通过加入少量稀土元素, 使非晶态 $\mathrm{Ni}$ 晶化温度提高 $200 \mathrm{~K}$ 以上; 通过加入 $\mathrm{Al}$ 再碱抽 $\mathrm{Al}$, 使非晶态 $\mathrm{Ni}$ 比表面积增加 100 倍以上; 通过加入功能助剂调节非晶态 $\mathrm{Ni}$ 的加氢选择性、增加抗酸 碱腐蚀性和磁性, 从而形成了系列非晶态Ni加氢催化剂 (商品名为 SRNA). 其中, SRNA-1 用于药物中间体加氢; SRNA-2用于葡萄 糖加氢制山梨醇; SRNA-3用于汽、柴油吸附脱硫; SRNA-4用于己内酰胺加氢精制; SRNA-5 用于苯甲酸加氢中替代Pd/C催化剂, 使 后者的用量减少了 $50 \%$.

关键词: 非晶态合金; 骨架镍; 加氢; 脱硫; 工业化

收稿日期: 2012-12-20. 接受日期: 2013-01-19. 出版日期: 2013-05-20.

*通讯联系人. 电话/传真: (010)82368011; 电子信箱: zongbn.ripp@sinopec.com

基金来源: 国家重点基础研究发展计划 (973计划, 2012CB224806).

本文的英文电子版由Elsevier出版社在ScienceDirect上出版(http://www.sciencedirect.com/science/journal/18722067). 